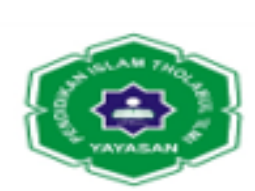

Jurnal Ilmiah METADATA

\title{
TINJAUAN YURIDIS KASUS PENCABULAN TERHADAP ANAK DIWILAYAH KABUPATEN DELISERDANG (Studi Kasus No. 116/Pid.B/2011/PN.LP/PB)
}

\author{
Muhammad Ridwan Lubis ${ }^{1)}$, Cut Nurita ${ }^{2)}$ \\ 1)Universitas Muslim Nusantara Alwashliyah Medan \\ ${ }^{2)}$ STIH Benteng Huraba \\ Email: muhammadridwanlubis76@gmail.com
}

Email: cutnurita123@gmail.com

\begin{abstract}
ABSTRAK
Perbuatan cabul pada masa sekarang ini semakin marak terjadi. Akibat perbuatan cabul akan membawa akibat korban mengalami kegoncangan jiwa dan mengalami kemunduran mental.

Dalam penulisan penelitian ini penulis menggunakan metode telaah pustaka (library research) untuk mentelaah data-data sekunder dan penelitian lapangan (field research) yaitu dengan melakukan penelitian di Pengadilan Negeri Medan.

Faktor terjadinya perbuatan cabul adalah karena dipengaruhi oleh faktor lingkungan seperti adanya kesempatan, kurangnya iman sehingga dapat membuat seseorang lupa mengenai apa yang dilarang oleh agama dan apa yang disuruh oleh agama, melihat atau mengakses situs-situs internet yang menampilkan adegan dan gambar-gamabr pornografi, sehingga internet yang menampilkan gambar dan adegan pornografi harus dihilangkan, karena dapat mempengaruhi cara berfikir seseorang, jika dibiarkan akan menjadi krisis dalam dirinya sehingga akan melakukan perbuatan yang melanggar hukum yaitu perbuatan cabul.
\end{abstract}

Berdasarkan analisa data di atas, maka dapat ditarik kesimpulan bahwa untuk menanggulangi perbuatan cabul adalah dengan penanggulangan secara preventif seperti memberikan pendidikan seks, pendidikan agama dan keharmonisan keluarga, serta peningkatan pengawasan masyarakat terhadap gejala-gejala sosial yang kurang baik yang timbul ditengah-tengah masyarakat. Usaha lain dengan cara represif yaitu dengan menjatuhkan hukuman yang berat kepada pelaku sehingga jera dalam melakukan perbuatan cabul. Sedangkan rehabilitatif adalah usaha pembinaan yang dilakukan terhadap orang yang melakukan perbuatan cabul sehingga tidak mengulangi perbuatannya tersebut.

Kata Kunci : Tinjauan Yuridis, Pencabulan, Anak

\section{PENDAHULUAN}

Setiap orang pasti akan berpendapat bahwa anak merupakan generasi yang akan meneruskan perjuangan dan cita-cita seluruh bangsa-bangsa di belahan bumi ini. Merekalah nantinya yang akan menjadi pemimpin baru yang siap untuk menghadapi 


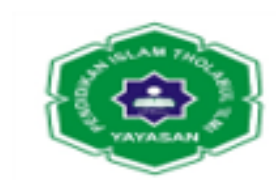

\section{Jurnal Ilmiah METADATA}

tantangan baru seiring dengan perkembangan zaman. Hal ini secara tegas dirumuskan dalam butir c konsiderans Undang-Undang Nomor 23 Tahun 2002 Tentang Perlindungan Anak yang berbunyi "bahwa anak adalah tunas, potensi, dan generasi muda penerus cita-cita perjuangan bangsa, memiliki peran strategis dan mempunyai ciri dan sifat khusus yang menjamin kelangsungan eksistensi bangsa dan negara pada masa depan.

Perlindungan hak anak bukan hanya merupakan tugas pemerintah dan orang tuanya saja, melainkan juga tugas masyarakat secara umum. Kenyataannya, tidak seluruh anak yang ada di negara ini mendapatkan perlindungan hak secara penuh, namun banyak anak semakin menjadi sosok yang terancam oleh perlakuan orangorang dewasa maupun teman sebaya. Jika kita perhatikan pemberitaan di berbagai media massa, baik media elektronik maupun media cetak, kita akan menemukan bahwa semakin banyak anak-anak yang menjadi korban kejahatan di seluruh Indonesia, baik secara fisik, psikis, bahkan seksual. Masalah kejahatan terhadap anak ini bukan hanya menjadi masalah bangsa Indonesia saja, tetapi menjadi masalah hampir seluruh negara-negara di dunia.

Tindak pidana terhadap anak terjadi di seluruh kota yang ada di Indonesia. Bentuk tindak pidana tersebut juga berbeda-beda. Mulai dari perbuatan cabul, penganiayaan, perdagangan anak, eksploitasi seksual anak, bahkan pembunuhan anak. Keadaan ini tentu saja merupakan suatu keadaan yang sangat memprihatinkan . Potensi dan posisi anak sebagai generasi penerus bangsa tampaknya bukan lagi menjadi alasan untuk memperlakukan anak sebagai seseorang yang harus dilindungi bagi sejumlah orang, tetapi justru anak sebagai makhluk yang rentan dan belum banyak mengerti tentang segala sesuatu, semakin dimanfaatkan oleh orang lain untuk melakukan tindak pidana terhadap anak. Fakta itu semakin terkuak, dimana anak yang seharusnya tumbuh berkembang dalam dunianya dan menikmati masa kecilny a yang bahagia dan tanpa beban harus dirampas hak-haknya oleh orang-orang yang tidak bertanggung jawab.

Minimnya lapangan pekerjaan yang tersedia dan masalah tuntutan kebutuhan hidup (ekonomi) di masyarakat menyebabkan munculnya berbagai macam kejahatan/tindak pidana.Salah satunya adalah pidana kesusilaan dengan kekerasan. Di berbagai massa media cetak maupun elektronik banyak diberitakan 


\section{Jurnal Ilmiah METADATA}

mengenai kesusilaan yang dilakukan oleh pelaku dengan meggunakan kekerasan atau ancaman kekerasan memaksa seorang perempuan yang bukan istrinya untuk bersetubuh dengan dia.

Di dalam Kitab Undang-undang Hukum Pidana (KUHP) sebenarya telah di atur ketentuan mengenai sanksi pidana terhadap pelaku tindak pidana pencabulan dengan kekerasan, namun pada kenyataanya kejahatan ini masih saja terjadi di banyak tempat dan tersembunyi dalam kehidupan masyarakat. Tidak jarang kasus tesebut lolos dari jeratan hukum yang berlaku, bahkan ad yang berhenti sampai pada tingkat pemeriksaan oleh kepolisian maupun kejaksaan sehingga tidak sampai di proses di pengadilan.

Untuk mewujudkan keberhasilan penegakan hukum dalam memberantas maraknya kasus pencabulan dengan kekerasan sangat di perlukan pemantapan koordinasi kerjasama yang serius baik dari aparat kepolisian, aparat kejaksaan maupun hakim-hakim di pengadilan. Putusan hakim pemeriksa kasus pencabulan dengan kekerasan di berbagai pengadilan berfariasi. Bahkan ada kasus pencabulan dengan kekerasan yang hanya di vonis main-main dengan hukum penjara enam bulan. Hal mana dapat di benarkan karena dalam batas-batas maksimum dan minimum (satu hari smpai dua belas tahun) tersebut hakim bebas untuk bergerak untuk mendapatkan pidana yang tepat.

Didalam menyelenggarakan sistem penyelenggara hukum pidana (Criminal Justice Sistem) maka pidana menempati suatu posisi sentral. Hal ini di sebabkan karena putusan di dalam pemidanaan akan mempunyai konsekuensi yang luas, lebih-lebih kalau putusan pidana tersebut di anggap tidak tepat, maka akan menimbulkan reaksi yang "Kontroversial", sebab kebenaran di dalam hal ini sifatnya adalah relatif tegantung dari mana kita memandangya.

Persoalan pidana ini adalah sangat kompleks dan mengandung makna yang sangat mendalam, baik yuridis maupun sosiologis. Sebagai mana di ketahui bahwa tindak pidana itu adalah perbuatan orang, pada dasarnya yang dapat melakukan tindak pidana itu manusia ( natuurlijke personen). Perbutan orang tersebut adalah titik penghubung dan dasar untuk pemberian pidana. Dipidananya seorang tidaklah cukup apabila orang tersebut telah melakukan perbuatn yang 
bertentangan dengan hukum atau bersifat melawan hukum, namun untuk adanya pemidanaan diperlukan syarat bahwa orang yang melakukan perbuatan itu mempunyai kesalahan atau bersalah (subjectief guilt).

Pada dasarnya seseorang telah merlakukan suatu tindak pidana dapat dikenai saksi pidana apabila perbuatannya tersebut memenuhi unsur-unsur tindak pidana. Unsur-unsur tindak pidana yang harus di penuhi antara lain adalah suatu perbuatan memenuhi rumusan undang-undang dan bersifat melawan hukum dilakukan oleh seseorang atau sekelompok orang yang di anggap mampu bertanggungjawab. Tindak pidana pencabulan dengan kekerasan diancam dalam pasal 285 dan 289 KUHP memutuskan "Barang siapa dengan kekerasan atau ancaman. Kekerasan memaksa seorang wanita bersetubuh dengan dia di luar perkawinan, diancam karena melakukan kesusilaan, dengan pidana paling lama dua belas tahun".

\section{METODE PENELITIAN}

Penelitian ini tergolong sebagai penelitian hukum normatif. Data penelitian ini bersumber dari data sekunder yang bersumber dari bahan-bahan hukum, yang terdiri dari bahan hukum primer, sekunder dan tersier. Penelitian ini menggunakan pendekatan undang-undang dan pendekatan konseptual. Analisis data dalam penelitian ini menggunakan analisis data kualitatif.

\section{HASIL DAN PEMBAHASAN}

\section{A. Tinjauan Umum Tentang Pencabulan}

Dalam hal pengertian pencabulan, pendapat para ahli dalam mendefinisikan tentang pencabulan berbeda-beda seperti yang dikemukakan oleh Abdul Wahid dan Muhammad Irfan, pencabulan adalah suatu usaha melampiaskan nafsu seksual oleh seorang laki-laki terhadap seorang perempuan dengan cara menurut moral dan atau hukum yang berlaku melanggar. ${ }^{7}$

7 Abdul Wahid dan Muhammad Irfan, Perlindungan Terhadap Korban Kekerasan Seksual (Advokasi Atas Hak Asasi Perempuan), Refika Aditama, Bandung, 2001,h.17 


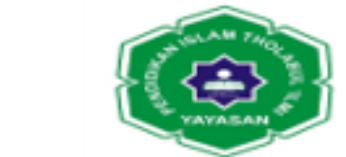 \\ Jurnal Ilmiah METADATA}

Dari pendapat tersebut, berarti pencabulan tersebut di satu pihak merupakan suatu tindakan atau perbuatan seorang laki-laki yang melampiaskan nafsu seksualnya terhadap seorang perempuan yang dimana perbuatan tersebut tidak bermoral dan dilarang menurut hukum yang berlaku.

Adami Chazawi mengatakan pencabulan ialah seorang pria yang memaksa pada seorang wanita bukan isterinya untuk melakukan persetubuhan dengannya dengan ancaman kekerasan, yang mana diharuskan kemaluan pria telah masuk ke dalam lubang kemaluan seorang wanita yang kemudian mengeluarkan air mani. ${ }^{8}$

Dari pendapat Adami Chazawi di atas, bahwa pencabulan tersebut adalah seorang pria yang melakukan upaya pemaksaan dan ancaman serta kekerasan persetubuhan terhadap seorang wanita yang bukan isterinya dan dari persetubuhan tersebut mengakibatkan keluarnya air mani seorang pria. Jadi unsurnya tidak hanya kekerasan dan persetubuhan akan tetapi ada unsur lain yaitu unsur keluarnya air mani, yang artinya seorang pria tersebut telah menyelesaikan perbutannya hingga selesai, apabila seorang pria tidak mengeluarkan air mani maka tidak dapat dikategorikan sebagai pencabulan.

Asumsi yang tak sependapat dalam hal mendefinisikan pencabulan tidak memperhitungkan perlu atau tidaknya unsur mengenai keluarnya air mani seperti yang dikemukakan oleh PAF Lamintang dan Djisman Samosir yang berpendapat "perkosaan adalah perbuatan seseorang yang dengan kekerasan atau ancaman kekerasan memaksa seorang wanita untuk melakukan persetubuhan di luar ikatan perkawinan dengan dirinya". 9

Dari pendapat tersebut, ini membuktikan bahwa dengan adanya kekerasan dan ancaman kekerasan dengan cara dibunuh, dilukai, ataupun dirampas hak asasinya yang lain merupakan suatu bagian untuk mempermudah dilakukannya suatu persetubuhan.

${ }^{8}$ AdamiChazawi, Tindak Pidana Mengenai Kesopanan, Raja Grafindo Persada, Jakarta, 9 P.A.F. Lamintang, Dasar-Dasar Hukum Pidana Indonesia, Citra Aditya Bakti, 1997, h. 21 


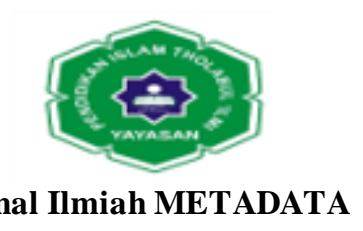

Menurut Arif Gosita, perkosaan dapat dirumuskan dari beberapa bentuk perilaku yang antara lain sebagai berikut :

a. Korban pencabulan harus seorang wanita, tanpa batas umur (objek). Sedangkan ada juga seorang laki-laki yang diperkosa oleh wanita.

b. Korban harus mengalami kekerasan atau ancaman kekerasan. Ini berarti tidak ada persetujuan dari pihak korban mengenai niat dan tindakan perlakuan pelaku.

c. Persetubuhan di luar ikatan perkawinan adalah tujuan yang ingin dicapai dengan melakukan kekerasan atau ancaman kekerasan terhadap wanita tertentu. Dalam kenyataan ada pula persetubuhan dalam perkawinan yang dipaksakan dengan kekerasan, yang menimbulkan penderitaan mental dan fisik. Walaupun tindakan ini menimbulkan penderitaan korban, tindakan ini tidak dapat digolongkan sebagai suatu kejahatan oleh karena tidak dirumuskan terlebih dahulu oleh pembuat undangundang sebagai suatu kejahatan. ${ }^{10}$

Dari perumusan di atas menunjukan bahwa posisi perempuan ditempatkan sebagai objek dari suatu kekerasan seksual (pencabulan) karena perempuan identik dengan lemah, dan laki laki sebagai pelaku dikenal dengan kekuatannya sangat kuat yang dapat melakukan pemaksaan persetubuhan dengan cara apapun yang mereka kehendaki meskipun dengan cara kekerasan atau ancaman kekerkasan. Fungsi dari kekerasan tersebut dalam hubungannya dengan tindak pidana adalah sebagai berikut :

a. Kekerasan yang berupa cara melakukan suatu perbuatan. Kekerasan di sini memerlukan syarat akibat ketidakberdayaan korban. Ada causal verband antara kekerasan dengan ketidakberdayaan korban. Contohnya kekerasan pada pencabulan, yang digunakan sebagai cara dari memaksa bersetubuh. Juga pada pemerasan (Pasal 368), yang mengakibatkan korban tidak berdaya, dengan ketidakberdayaan itulah yang menyebabkan korban dengan terpaksa menyerahkan benda, membuat utang atau menghapuskan piutang.

b. Kekerasan yang berupa perbuatan yang dilarang dalam tindak pidana bukan merupakan cara melakukan perbuatan. Contohnya kekerasan pada pasal 211 atau Pasal 212. ${ }^{11}$

Sedangkan ancaman kekerasan mempunyai aspek yang penting dalam pencabulan yang antara lain sebagai berikut :

10 Arif Gosita, Masalah Korban Kejahatan (Kumpulan Karangan), Akademika Pressindo, Jakarta, 1993, h.47

${ }^{11}$ Ibid, h.49 


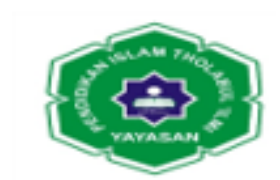

\section{Jurnal Ilmiah METADATA}

a. Aspek obyektif, ialah :

1) Wujud nyata dari ancaman kekerasan yang berupa perbuatan persiapan dan mungkin sudah merupakan perbuatan permulaan pelaksanaan untuk dilakukannya perbuatan yang lebih besar yakni kekerasan secara sempurna.

2) Menyebabkan orang menerima kekerasan menjadi tidak berdaya secara psikis, berupa rasa takut, rasa cemas (aspek subyektif yang diobjektifkan).

b. Aspek subyektif, ialah timbulnya suatu kepercayaan bagi si penerima kekerasan (korban) bahwa jika kehendak pelaku yang dimintanya tidak dipenuhi yang in casu bersetubuh dengan dia, maka kekerasan itu benarbenar akan diwujudkan. Aspek kepercayaan ini sangat penting dalam ancaman kekerasan sebab jika kepercayaan ini tidak timbul pada diri korban, tidaklah mungkin korban akan membiarkan dilakukan suatu perbuatan terhad ap dirinya. ${ }^{12}$

Kekerasan dan ancaman kekerasan tersebut mencerminkan kekuatan fisik laki-laki sebagai pelaku merupakan suatu faktor alamiah yang lebih hebat dibandingkan perempuan sebagai korban, sehingga laki-laki menampilkan kekuatan yang bercorak represif yang menempatkan perempuan sebagai korbannya. Karakteristik utama dalam perkosaan ialah "bahwa perkosaan terutama bukan ekspresi agrsivitas (baca: kekerasan) dari seksualitas (the agressive expression of sexuality) akan tetapi merupakan ekspresi seksual dari suatu agresivitas (sexual expression of aggression)".

Dalam Kitab Undang-undang Hukum Pidana (KUHP), pengertian perkosaan tertuang pada Pasal 285 yang berbunyi "barangsiapa dengan kekerasan atau ancaman kekerasan memaksa seorang wanita yang bukan isterinya bersetubuh dengan dia, diancam karena melakukan perkosaan dengan pidana penjara paling lama dua belas tahun". Dalam pasal tersebut dapat ditarik kesimpulan antara lain :

a. Korban pencabulan harus seorang wanita, tanpa klasifikasi umur yang signifikan. Seharusnya wanita dapat dibedakan yang antara lain sebagai berikut :

1) Wanita belum dewasa yang masih perawan.

2) Wanita dewasa yang masih perawan.

${ }^{12}$ Ibid, h.50 


\section{(ㄷ) \\ Jurnal Ilmiah METADATA}

3) Wanita yang sudah tidak perawan lagi.

4) Wanita yang sedang bersuami.

b. Korban mengalami pemaksaan bersetubuh berupa kekerasan atau ancaman kekerasan. Ini berarti tidak ada persetujuan dari pihak korban mengenai niat dan tindakan perlakuan pelaku.

Dalam perkembangannya yang semakin maju dan meningkat dengan pesat ini, dalam hal ini muncul banyak bentuk penyimpangan khususnya pencabulan seperti bentuk pemaksaan persetubuhan yang dimana bukan vagina (alat kelamin wanita) yang menjadi target dalam pencabulan akan tetapi anus atau dubur (pembuangan kotoran manusia) dapat menjadi target dari pencabulan yang antara lain sebagai berikut :

a. Perbuatannya tidak hanya bersetubuh (memasukkan alat kelamin ke dalam vagina), tetapi juga :

1) Memasukkan alat kelamin ke dalam anus atau mulut.

2) Memasukkan sesuatu benda (bukan bagian tubuh laki-laki) ke dalam vagina atau mulut wanita.

b. Caranya tidak hanya dengan kekerasan/ ancaman kekerasan, tetapi juga dengan cara apapun di luar kehendak/ persetujuan korban.

c. Objeknya tidak hanya wanita dewasa yang sadar, tetapi wanita yang tidak berdaya/ pingsan dan di bawah umur, juga tidak hanya terhadap wanita yang tidak setuju (di luar kehendaknya), tetapi juga terhadap wanita yang memberikan persetujuannya karena dibawah ancaman, karena kekeliruan/ kesesatan/ penipuan atau karena di bawah umur. ${ }^{13}$

Pelaku pencabulan terhadap anak-anak di bawah umur yang dapat juga disebut dengan chid molester, dapat digolongkan ke dalam lima kategori yaitu:

a. Immature : para pelaku melakukan pencabulan disebabkan oleh ketidakmampuan mengidentifikasikan diri mereka dengan peran seksual sebagai orang dewasa.

b. Frustated : para pelaku melakukan kejahatannya (pencabulan) sebagai reaksi melawan frustasi seksual yang sifatnya emosional terhadap orang dewasa. Sering terjadi mereka beralih kepada anak-anak mereka sendiri (incest) ketika merasa tidak seimbang dengan istrinya.

c. Sociopathic : para pelaku pencabulan yang melakukan perbuatanya dengan orang yang sama sekali asing baginya, suatu tindakan yang keluar dari kecenderungan agresif yang terkadang muncul.

d. Pathological : para pelaku pencabulan yang tidak mampu mengontrol dorongan seksual sebagai hasil psikosis, lemah mental, kelemahan organ

${ }^{13}$ Abdul Wahid dan Muhammad Irfan, Op.Cit, h.72 


\section{(2) \\ Jurnal Ilmiah METADATA}

tubuh atau kemerosotan sebelum waktunya (premature senile deterioration).

e. Miscellaneous : yang tidak termasuk semua kategori tersebut di atas. ${ }^{14}$

Pencabulan merupakan suatu tindak kejahatan yang pada umumnya diatur dalam pasal 285 KUHP, yang bunyinya adalah sebagai berikut : Barangsiapa dengan kekerasan atau ancaman kekerasan memaksa seorang wanita yang bukan istrinya bersetubuh dengan dia, diancam karena melakukan perkosaan dengan pidana penjara paling lama dua belas tahun.

Jika diperhatikan dari bunyi pasal tersebut, terdapat unsur-unsur yang antara lain sebagai berikut:

a. "Barangsiapa" merupakan suatu istilah orang yang melakukan.

b. "Dengan kekerasan atau ancaman kekerasan" yang artinya melakukan kekuatan badan, dalam pasal 289 KUHP disamakan dengan menggunakan kekerasan yaitu membuat orang jadi pingsan atau tidak berdaya.

c. "Memaksa seorang wanita yang bukan istrinya bersetubuh dengan dia" yang artinya seorang wanita yang bukannya istrinya mendapatkan pemaksaan bersetubuh di luar ikatan perkawinan dari seorang laki-laki.

Pencabulan dalam bentuk kekerasan dan ancaman kekerasan untuk bersetubuh dengan anak di bawah umur diatur juga dalam Undang-undang No 23 Tahun 2002 Tentang Perlindungan Anak pada pasal 81 ayat (1) dan (2) yang menyebutkan :

a. Setiap orang dengan sengaja melakukan kekerasan atau ancaman kekerasan memaksa anak melakukan persetubuhan dengannya atau dengan orang lain, dipidana dengan pidana penjara paling lama 15 (lima belas) tahun dan paling singkat 3 (tiga) tahun dan denda paling banyak Rp 300.000.000,00 (tiga ratus juta rupiah) dan paling sedikit Rp 60.000.000,00 (enam puluh juta rupiah).

b. Ketentuan pidana sebagaimana dimaksud dalam ayat (1) berlaku pula bagi setiap orang yang dengan sengaja melakukan tipu muslihat, serangkaian kebohongan, atau membujuk anak melakukan persetubuhan dengannya atau dengan orang lain.

${ }^{14}$ Ibid, h.75 


\section{Jurnal Ilmiah METADATA}

Jika diperhatikan pada pasal tersebut di atas, maka unsur-unsur pencabulan ialah sebagai berikut :

a. Setiap orang, yang berarti subyek atau pelaku.

b. Dengan sengaja, yang berarti mengandung unsur kesengajaan (dolus).

c. Melakukan kekerasan atau ancaman kekerasan, yang berarti dalam prosesnya diperlakukan dengan menggunakan kekerasan atau ancaman kekerasan. Memaksa anak melakukan persetubuhan dengannya atau dengan orang lain, yang berarti ada suatu pemaksaan dari pelaku atau orang lain untuk bersetubuh dengan seorang anak (korban).

d. Berlaku pula bagi setiap orang yang dengan sengaja melakukan tipu muslihat, serangkaian kebohongan, atau membujuk anak melakukan persetubuhan dengannya atau dengan orang lain, yang berarti bahwa perbuatan tersebut dapat dilakukan dengan cara menipu, merayu, membujuk dan lain sebagainya untuk menyetubuhi korbannya.

\section{B. Faktor-Faktor Pelaku Melakukan Perbuatan Cabul Terhadap Anak}

Berdasarkan hasil penelitian yang penulis lakukan di dapat data banyaknya kasus perbuatan cabul yang terjadi. Tidaklah mudah untuk menemukan suatu penyebab yang paling dominan untuk mendorong terjadinya perbuatan cabul akibat pengaruh internet.

Berdasarkan data yang diperoleh di Pengadilan Negeri Lubuk Pakam diketahui bahwa kejahatan pada tahun 2012 dapat dilihat dalam bentuk tabel seperti berikut :

\section{Tabel 1}

Kasus Kejahatan Pada Tahun 2012

\begin{tabular}{|c|c|c|}
\hline No & Jenis Kejahatan & Jlh. Kasus \\
\hline 1 & Kejahatan terhadap nyawa & 7 \\
\hline 2 & Penganiayaan & 6 \\
\hline 3 & Menyebabkan mati/luka karena kealpaan & - \\
\hline 4 & Perkosaan & 30 \\
\hline 5 & Penipuan & - \\
\hline 6 & Penadahan & 9 \\
\hline 7 & Narkoba & 33 \\
\hline 8 & Judi & 16 \\
\hline 9 & Perkosaan/Susila & \\
\hline
\end{tabular}




\section{Jurnal Ilmiah METADATA}

Sumber : Pengadilan Negeri Lubuk Pakam, Tahun 2012

Berdasarkan data tersebut terlihat bahwa angka kejahatan menunjukan kejahatan perkosaan/susila termasuk di dalamnya perbuatan cabul menempati urutan ketiga yaitu sebanyak 16 buah kasus.

Kejahatan a susila yang dilakukan pada tahun 2007 s/d tahun 2012 dapat dilihat pada tabel sebagai berikut :

\section{Tabel 2}

Kejahatan A Susila Di Pengadilan Negeri Lubuk Pakam

Tahun 2007 s/d 2012

\begin{tabular}{|c|c|c|}
\hline No & Tahun & Jlh. Kasus \\
\hline 1 & 2007 & 5 \\
\hline 2 & 2008 & 19 \\
\hline 3 & 2009 & 14 \\
\hline 4 & 2010 & 5 \\
\hline 5 & 2011 & 14 \\
\hline 6 & 2012 & 16 \\
\hline
\end{tabular}

Sumber : Pengadilan Negeri Lubuk Pakam, Tahun 2012

Berdasarkan data statistik kejahatan a susila yang terjadi di daerah hukum Pengadilan Negeri Lubuk Pakam terlihat jumlahnya naik turun dan jumlah yang terbanyak dalam kasus tindak kejahatan a susila terjadi pada tahun 2008 dengan 19 kasus.

Berdasarkan hasil penelitian di Pengadilan Negeri Lubuk Pakam, dalam hal pencabualn terhadap anak di bawah umur dapat dilakukan dengan beragam modus operandi sebagai berikut :26

1. Pelaku melakukan tindak pidana perkosaan terhadap anak di bawah umur dengan cara pelaku mengajak berkenalan dengan anak yang akan menjadi korbannya, pelaku menawarkan sesuatu seperti mengantarkannya pulang ataupun menjanjikan sesuatu. Setelah korban menerima penawaran tersebut pelaku melakukan pencabulan.

2. Pelaku melakukan tindak pidana pencabulan terhadap anak di bawah umur dengan cara atau modus memberikan minuman yang dimana minuman tersebut telah dicampurkan obat yang membuat anak menjadi tidur atau

${ }^{26}$ Hasil Wawancara Dengan Budi Haryanto, Hakim Pengadilan Negeri Lubuk Pakam Tanggal 07 Mei 2013. 


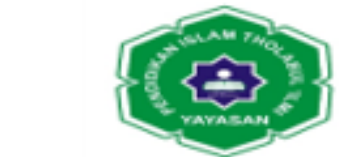 \\ Jurnal Ilmiah METADATA}

pingsan, obat-obatan tersebut dengan mudah didapatkan di apotek tanpa memerlukan resep dokter yang antara lain seperti Ctm (Chlorpheniramin) atau Diazepam dan obat bius lainnya yang dapat menimbulkan rasa kantuk yang kuat. Setelah korbannya tidak sadarkan diri kemudian pelaku melakukan perkosaan.

3. Pelaku melakukan pencabualan terhadap anak di bawah umur dengan cara pelaku yang mempunyai jiwa yang dekat dengan anak-anak atau yang sering berada di lingkungan anak-anak, mengajak bermain ataupun berbicara dengan anak kemudian mengajaknya ke suatu tempat dengan iming-iming akan diberi sejumlah uang atau hadiah, setelah anak tersebut mengiyakan ajakan pelaku, setelah itu pelaku melakukan pencabulan.

4. Pelaku pencabulan yang menjadikan anak sebagai obyek perkosaannya dengan cara berawal dari media elektronik berupa jejaring sosial seperti yahoo, facebook, friendster dan lain-lain yang dimana usia seorang anak sudah dapat mengetahui dan memakai kemajuan teknologi tersebut, setelah pelaku berbincang atau dengan kata lain chatting dengan korbannya anak, kemudian anak tersebut diajak bertemu dengan pelaku dan setelah pelaku bertemu dengan anak yang akan menjadi objeknya, kemudian pelaku menggiring anak tersebut ke suatu tempat untuk melakukan niat jahat pelaku yaitu pencabulan.

5. Pelaku melakukan pencabulan terhadap anak di bawah umur dengan modus atau cara menculik anak yang akan menjadi objek pencabulannya dan membawanya ke suatu tempat kemudian pelaku melaksanakan niat jahatnya yaitu mencabuli anak tersebut.

6. Pelaku melakukan pencabulan terhadap anak di bawah umur dengan modus atau cara, pelaku menghipnotis atau membuat anak tersebut tidak sadar dengan kekuatan alam bawah sadar yang di buat oleh pelaku sehingga apa yang pelaku katakan anak atau korbannya akan selalu menurutinya dari keadaan seperti pelaku melakukan niat jahatnya dengan mencabuli anak atau korbannya. 


\section{(ㄷ) \\ Jurnal Ilmiah METADATA}

7. Pelaku melakukan pencabulan terhadap anak di bawah umur dengan cara atau modus kekerasan dan ancaman kekerasan terhadap anak atau korbannya sehingga anak tersebut menjadi takut, dan pelaku bebas melakukan pencabulan terhadap korbannya.

Dari beragam bentuk modus yang dilakukan oleh para pelaku disebabkan oleh suatu faktor yang mendukung perbuatan tersebut. Menurut Budi Haryanto, hakim Pengadilan Negeri Lubuk Pakam disebutkan bahwa ada beberapa hal yang dianggap merupakan penyebab dari meningkatnya perbuatan cabul, yaitu :

1. Lemahnya kesadaran hukum pelaku, hal ini menyebabkan ketidaktahuan mereka tentang akibat-akibat hukum dilakukannya perbuatan cabul.

2. Kadar iman dan taqwa dan penghayatan terhadap agama para pelaku perbuatan cabul sangat lemah, sehingga menyebabkan mereka tidak mengetahui atau tidak takut akan dosa karena perbuatan cabul tersebut yang jelas-jelas bertentangan dengan agama.

3. Adanya kecenderungan pergaulan bebas yang mengakibatkan perbuatan cabul yang bermuara dari globalisasi berbagai arus budaya asing dan informasi negatif tanpa filter yang mampu menjaringnya yang kesemuanya itu dimanifestasikan dalam bentuk perubahan-perubahan nilai sosial budaya. $^{27}$

Untuk kasus terjadinya perbuatan cabul dibagi faktor-faktor timbulnya perbuatan cabul itu dari dua segi yaitu faktor yang datangnya dari dalam (intern) dan faktor yang datangnya dari luar (ekstern).

1. Faktor intern meliputi antara lain :

a. Rendahnya penghayatan agama.

Perbuatan cabul akibat pengaruh internet yang dilakukan juga tidak terlepas dari faktor lemahnya keimanan tersebut, sebab jika iman tersebut kuat, sebesar apapun godaan akan dapat diatasi. Walaupun mungkin hukum dunia tidak mampu menjangkau kejahatan abortus yang dilakukan tersebut, namun berkat keyakinannya terhadap ajaran agama dan mengingat akan hukum Tuhan, seorang tidak akan berani melakukan perbuatan cabul akibat pengaruh internet

${ }^{27}$ Hasil Wawancara Dengan Budi Haryanto, Hakim Pengadilan Negeri Lubuk Pakam Tanggal 07 Mei 2013. 


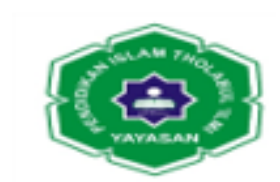

\section{Jurnal Ilmiah METADATA}

b. Rendahnya mental dan daya emosional.

Keadaan mental seseorang adalah suatu keadaan bathin berupa cara berpikir dan berperasaan. Jika keadaan mental seseorang itu rendah, maka akan dapat mengakibatkan tingkah laku yang menyimpang.

Jika dikaji lebih mendalam lagi maka dapat dikatakan bahwa keadaan mental seseorang itu dibangun oleh daya inteligensia ditambah dengan aturan-aturan moral agar seseorang dapat mengenal serta menilai suatu perbuatan. Pengertian intelgensia di sini merupakan kemampuan seseorang yang memungkinan memperoleh ilmu pengetahuan dan mengamalkan ilmu tersebut dalam hubungannya dengan lingkungan dan masalah-masalah yang timbul. ${ }^{28}$

Selain itu keadaan tersebut juga dipengaruhi oleh daya emosional sebagai cerminan jiwa seorang anak dalam menghadapi suatu masalah. Daya emosi yang terdapat dalam jiwa seseorang biasanya timbul dengan spontan serta mudah berubah (labil), serba ingin mengetahui dan mencoba sesuatu yang baru. Biasanya seorang yang melakukan perbuatan cabul akibat pengaruh internet, maka orang tersebut di dalam bertindak dan berfikir tidak secara matang dalam mengahadapi suatu masalah.

Kaitannya dengan perbuatan cabul akibat pengaruh internet yang dilakukannya adalah bahwa orang tersebut tidak mampu menempatkan daya intelegensinya untuk menilai secara benar tentang baik buruknya prilaku perbuatan cabul yang dilakukannya. Rendahnya mental serta perasaan emosional ini mengakibatkan orang tersebut tidak mampu untuk mengendalikan diri sehingga banyak yang terjerumus dalam perbuatan cabul tersebut. ${ }^{29}$

\section{Faktor ekstern.}

Disamping faktor-faktor intern seperti di sebutkan di atas, juga terdapat faktor ekstern yang sangat besar pengaruhnya dalam terjadinya perbuatan cabul akibat pengaruh internet. Faktor esktern ini antara lain :

a. Faktor Lingkungan. Faktor lingkungan merupakan salah satu faktor yang dapat mendukung terjadinya tindak pidana pencabulan terhadap anak di bawah umur. Hal ini dapat terjadi dikarenakan situasi dan keadaan dari lingkungan

${ }^{28}$ Kartini Kartono.,Op.Cit, h.38.

${ }^{29}$ Hasil Wawancara Dengan Budi Haryanto, Hakim Pengadilan Negeri Lubuk Pakam Tanggal 07 Mei 2013. 


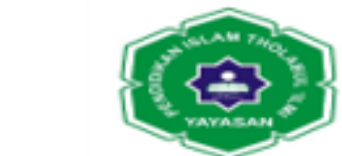 \\ Jurnal Ilmiah METADATA}

tempat tinggal yang mendukung dan memberi kesempatan untuk melakukan suatu tindak pidana pencabulan terhadap anak di bawah umur, yang antara lain:

1) Pergaulan di lingkungan masyarakat sekitar yang terkadang sering kali melanggar norma-norma yang berlaku seperti perkumpulan atau tongkrongan yang seringkali berperilaku yang tidak sopan seperti mengganggu wanita, minum-minuman beralkohol dan lain sebagainya.

2) Lingkungan tempat tinggal yang cenderung mendukung terjadinya kejahatan, seperti lampu penerangan jalanan yang tidak memadai sehingga menimbulkan daerah tersebut menjadi gelap, dan sepi yang dimana hal tersebut dapat mendukung terjadinya tindak pidana pencabulan.

3) Kurang efisiennya sistem pengamanan dari suatu daerah oleh masyarakat maupun aparat kemananan setempat sehingga menyebabkan daerah tersebut rawan dan sering timbul kejahatan.

4) Keadaan di lingkungan keluarga yaitu kurang efisiennya antisipasi keluarga terhadap anak seperti seorang anak dibiarkan bermain atau berpergian sendirian tanpa pendampingan dan pengawasan secara intensif sehingga anak dapat diawasi dengan baik, dengan siapa anak bermain ataupun dengan siapa teman yang baru anak kenal dan ketahui.

5) Keadaan di lingkungan keluarga dalam hal hubungan seksual suami istri dapat mendukung terjadinya tindak pidana pencabulan seperti seorang ayah mencabuli anaknya (incest) yang disebabkan hasrat seksual ayah tidak dapat dipenuhi oleh sang ibu dan menyebabkan ayah lepas kontrol dan mencabuli anaknya sendiri, hal tersebut lebih cenderung pelakunya ialah ayah tiri tapi dapat juga dilakukan oleh ayah kandung atau saudarasaudara dari anak tersebut.

6) Keadaan di lingkungan pendidikan dapat juga mempengaruhi dikarenakan di lingkungan pendidikan juga harus di waspadai sebab banyak kasus pencabulan yang dilakukan oleh seorang pengajar ataupun teman sekolahnya yang disebabkan oleh kurangnya moralitas dan mentalitas dari pelaku sehingga membuat moralitas dan mentalitas yang tidak dapat 


\section{(ㅇ) \\ Jurnal Ilmiah METADATA}

bertumbuh dengan baik, membuat pelaku tidak dapat mengontrol nafsu atau perilakunya.

7) Keadaan lingkungan di jalanan bagi anak-anak yang berkehidupan di jalanan dapat mempengaruhi terjadinya tindak pidana pencabulan terhadap anak di bawah umur, dikarenakan kehidupan jalanan dapat dikatakan kehidupan yang sangat keras dan memiliki potensi yang relevan bagi suatu tindak pidana pencabulan, kebanyakan korbannya anak-anak jalanan yang berkehidupan sebagai pengamen dan pengemis, tidak selayaknya anakanak berada dalam lingkungan tersebut.

b. Faktor Ekonomi.

Ekonomi merupakan suatu penunjang kehidupan setiap manusia, ekonomi atau keuangan dapat merupakan faktor yang dapat mempengaruhi terjadinya suatu pencabualan terhadap anak di bawah umur. Dalam hal yang dimaksud tersebut ialah apabila seseorang mengalami himpitan atau kesusahan dalam bidang perekonomian, hal tersebut dapat menganggu akal pikirannya dan dapat mengakibatkan orang tersebut akan mengalami stres berat, sehingga dapat membuat orang tersebut dapat melakukan sesuatu hal yang tak bisa dikontrol oleh dirinya sendiri. Hal ini cenderung di kehidupan berkeluarga dan pengangguran yang dapat melakukan tindakan apa saja yang tak bisa dikontrol oleh dirinya sendiri akibat dari kemerosotan perekonomian dalam kehidupannya.

c. Kurangnya perhatian dalam rumah tangga

Dalam pembentukan pribadi seorang anak yang memegang peranan penting ialah keluarga atau orang tua. Lingkungan keluarga merupakan tempat pendidikan yang pertama dan utama bagi sebelum akan memasuki sekolah.

Para orang tua yang sibuk mengurusi urusannya masing-masing, si bapak sibuk dengan pekerjaannya mencari nafkah kadang ibu juga turut membantu suami untuk meringankan kehidupan rumah tangga atau bagi ibu yang lain dengan urusan di luar rumah.

Sebagaimana diketahui bahwa, semua ini tanpa disadari oleh pihak orang tua, dengan bebas pula bergabung dengan teman sebayanya untuk 


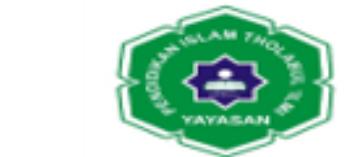 \\ Jurnal Ilmiah METADATA}

mencari kesenangan pada diri mereka sendiri yang telah menjurus kepada perbuatan kriminal seperti melakukan perkelahian, pencurian dan tindak pidana lainnya termasuk perbuatan cabul.

Dengan demikian peranan keluarga atau orang tua dalam menentukan pola-pola tingkah laku sebelum dewasa dan sesudahnya penting sekali untuk perkembangan selanjutnya. Hal inilah yang memberikan suatu gambaran tentang penyebab timbulnya perbuatan cabul akibat pengaruh internet, karena kurang perhatian dan pengawasan dari orang tua.

d. Pengaruh media massa khususnya internet

Salah satu faktor yang turut serta mempengaruhi terjadinya tindak pidana perkosaan terhadap anak di bawah umur ialah faktor media. Media merupakan sarana yang efisien dan efektif dalam menyebarluaskan informasi kepada masyarakat luas, karena dengan biaya yang relatif sesuai dengan kemampuan dan mampu menjangkau masyarakat dalam waktu yang cukup signifikan.

Faktor media tersebut meliputi media cetak seperti majalah-majalah atau bacaan-bacaan yang mengandung unsur pornografi dan faktor media lainnya ialah media elektronik seperti internet, film-film yang mengandung unsur pornografi dan lain-lain. Pornografi tersebut dapat mempengaruhi tindak pidana perkosaan terhadap anak di bawah umur, dikarenakan pornografi mengandung unsur negatif yang dapat menimbulkan seseorang terpengaruh dari media-media yang di lihatnya. Hal tersebut dapat menimbulkan nafsu seksual, rangsangan, dan pikiranpikiran tidak sehat, khususnya dikalangan dewasa.

Walaupun Undang-undang No 44 tahun 2008 tentang Pornografi tersebut telah diberlakukan, akan tetapi peredaran media yang mengandung unsur pornografi dapat beredar secara mudah di kalangan masyarakat, seakanakan para pembuat, pengedar dan kosumen film dan bacaan porno tidak menghiraukan keberlakuan undang-undang tentang pornografi tersebut.

Tidaklah berlebihan jika dikatakan, bahwa media kini. telah merupakan senjata ampuh perang urat syaraf dalam pergolakan pikiran, politik 


\section{당 \\ Jurnal Ilmiah METADATA}

dan ekonomi yang terjadi dewasa ini, teurtama jika dikelola oleh para ahli media, para propagandais, para spesialis yang mahir menggunakan sarana media yang ada. Bahkan manusia adalah dijadikan sasaran oleh media itu.

Jika media digunakan untuk mengarahkan orang ke jalan yang baik, maka pengarunya tiada taranya dalam gembangunan manusia. Tetapi, sebaliknya jika digunakan untuk kejahatan dan kesesatan, pengaruhnya-pun tidak terbayangkan betapa tragisnya bagi masyarakat terlebih-lebih bagi anakanak. Media yang digunakan itu adalah semua media yang bisa dicerna oleh akal pikiran manusia,

Salah satu sarana media yang paling berpengaruh terhadap perkembangan kehidupan dan jiwa masyarakat adalah terutama internet. Alat ini merupakan media yang membawakan gambar. Internet menyibukkan ind era penglihatan.

Pengaruh internet terhadap anak-anak ini merupakan hal yang sangat peka dan memerlukan pemikiran yang serius untuk menanggulangi segala akibat yang dapat merugikan perkembangan si-anak. Hal ini mengingat unsur psikologis bahwa si-anak belum dapat menetapkan suatu pilihan berdasarkan kriteria untung-ruginya. Dan timbulnya kejahatan anak-anak terutama perbuatan cabul akibat pengaruh internet pada akhirnya menjadi permasalahan yang membutuhkan perhatian dari semua pihak bagaimana upaya menanggulanginya, karena dalam masa ini sebenarnya merupakan saat pembentukan kepribadian si-anak tersebut.

Anak-anak yang turut melibatkan dan/atau terlibat dirinya dalam proses komunikasi internet disebabkan oleh sifat anak-anak yang masih bersifat meniru, mengikut-ikut saja juga karena sifatnya yang mudah terpengaruh, maka tanpa disadari akan melakukan perbuatan yang diketahuinya melalui internet, baik perbuatan yang positif (bermanfaat) dan/atau menimbulkan pengaruh yang negatif (kerugian) bagi dirinya dan lingkungannya.

Anak-anak turut menikmati kemajuan dalam bidang komunikasi, khususnya melalui internet. Anak-anak itu mengakses internet, melihat, 


\section{(ㄷ) \\ Jurnal Ilmiah METADATA}

meniru dan melakukan apa yang dilihatnya melalui internet tanpa mengerti dan tidak menyadari untuk apa ia berbuat demikian, hanya sesuai sifat hakekat manusia itu sendiri sebagai kodratnya yang bersifat meniru dan mengimbangi (kompensasi) dengan yang lain.

Oleh sebab itu anak-anak yang turut dalam proses komunikasi massmedia khususnya internet, seluruh gerak dan pikirannya dipengaruhi oleh internet, kecuali situasi keluarga dimana anak-anak itu menentukan lain karena didikan dan bimbingan orangtua dan keluarganya yang sudah dewasa atau karena sudah diajarkan bimbingan agama dalam keluarganya.

Hadirnya internet sedikit demi sedikit akan merubah pola kegiatan yang biasa dilakukan setiap harinya dari seorang anak. Mengingat anak-anak masih dalam masa perkembangan maka timbullah pertanyaan mengenai dampak internet terhadap perkembangan diri si-anak. Apakah internet itu berbahaya terhadap diri si-anak atau tidak.

Dalam era yang serba canggih ini, tekhnologi internet membuat pemirsanya menyaksikan gambar yang hidup dan merasa seperti keadaan aslinya, baik dalam bentuknya, warna, apalagi jika diikuti dengan suara yang turut mendukung penggambaran yang diinginkan. Karena dengan bentuk penyajian visual maupun auditifnya, imformasi yang disajikan internet lebih menarik. Selain karekteristik internet ini sendiri, faktor intern pada anak turut ikut menentukan minat anak terhadap internet. Anak yang tidak memiliki kegiatan (permainan) yang lain, akan menghabiskannya dengan bermain internet.

Internet dalam perkembangannya di Indonesia saat ini sudah bukan dianggap sebagai barang mewah Iagi. Begitu besar daya pikatnya terhadap seseorang, tidak terkecuali bagi orang yang sudah tua, dewasa remaja bahkan sampai pada anak-anak. Hal ini disatu pihak merupakan layanan yang memuaskan bagi yang mengakses, namun dipihak lain timbul rasa takut dan khawatir akibat tayangan di internet yang berisi adegan seperti dengan kriminalitas, pembunuhan, seksualitas dan lain-lain. 


\section{Jurnal IImiah METADATA}

Masalah seksualitas dalam internet di Indonesia dalam era globalisasi saat ini menjadi pusat perhatian, mengingat semakin banyaknya situs-situs yang menampilkan gambar-gambar seksualitas.

Bertitik tolak dari pengalaman ini, yang pada gilirannya akan mempengaruhi mentalitas dan kejiwaan si anak pada perkembangan yang tidak baik (negatif), kiranya sudah waktunya untuk mencari asalnya mangapa begitu banyak anak-anak yang justru paling menyenangi gambar-gambar yang menampilkan adegan-adegan yang hanya dikonsumsi untuk orang dewasa.

Dengan demikian jelaslah bahwa internet sebagai suatu alat atau sarana untuk suatu komunikasi secara massal dapat mempengaruhi tingkah laku dalam masyarakat luas. Pada dasarnya setiap orang sangat peka terhadap segala hal, memungkinkan untuk menimbulkan hasrat dari apa yang pernah didengar, ditonton dan dilihatnya. Hal ini mungkin disebabkan belum mempunyai kematangan jiwa dan pikiran yang cukup untuk memilih mana yang baik dan mana yang buruk, seseorang dapat menerima dan meniru apa yang dianggap baru tanpa memikirkan secara cermat dan tepat.

\section{KESIMPULAN}

Bahwa faktor terjadinya perbuatan cabul adalah karena dipengaruhi oleh faktor seperti : faktor individu, lingkungan, gambar atau internet yang menampilkan adegan pornografi serta kurangnya iman atau moral seseorang sehingga dapat membuat seseorang lupa mengenai apa yang dilarang oleh agama dan apa yang disuruh oleh agama.

Penerapan sistem pidana bagi pelaku yang melakukan perbuatan cabul terhadap anak di bawah umur menurut hukum yang berlaku di Indonesia seperti Kitab Undang-undang Hukum Pidana pasal 285, 286 dan 287 ayat (1) serta di dalam Undang-Undang No 23 Tahun 2002 tentang Perlindungan Anak yaitu dalam pasal 81 ayat (1) dan (2).

\section{DAFTAR PUSTAKA}

\section{A. Buku}


Abdul Wahid dan Muhammad Irfan, Hukum Pidana dan Perkembangan Masyarakat, Sinar Baru, Bandung 1983.

Adami Chazawi, Tindak Pidana Mengenai Kesopanan, RajaGrafindo Persada, Jakarta, 2005

Arif Gosita., Persyaratan Pembuatan Peraturan Perundangan-Undangan Anak Yang Baik, Lembaga Advokasi Anak Indonesia, Medan, 2001.

----------, Masalah Korban Kejahatan (Kumpulan Karangan), Akademika Pressindo, Jakarta, 1993

Achie Sudiarti Luhulima., Pemahaman Bentuk-Bentuk Tindak Kekerasan Terhadap Perempuan dan Alternatif Pemecahannya, Pusat Kajian Wanita dan Jender UI, Jakarta, 2000

Azis. Aminah, Aspek Perlindungan Anak, Usaha Nasional, Surabaya, 1998

B. Simanjuntak., Pengantar Kriminologi dan Pathologi Sosial, Tarsito, Bandung, 1992.

-------;Pengantar Psikologi Kriminal, Tarsito, Bandung, 1991.

Chainur Arrasyid., Suatu Pemikiran Tentang Psikologi Kriminal, FH. USU, Medan, 1999.

D. Soejono., Psikologi dan Ruang Lingkupnya, Tarsito, Bandung, 1994.

; Penanggulangan Kejahatan, Alumni,Bandung, 1993

GW. Bawengan., Psikologi Kriminal, Pradnya Paramita, Jakarta, 1992.

HM. Ridwan dan Ediwarman., Asas-asas Kriminologi, USU Pers, Medan, 1994

Irma Setyowati Soemitro., Aspek Hukum Perlindungan Anak, Bumi Aksara, Jakarta, 1990

Kartini Kartono., Psikologi Abnormal dan Patologi Seks,Alumni, Bandung, 1994 ;Patologi Sosial, CV. Rajawali, Jakarta, 1993

Leden Marpaung., Kejahatan Terhadap Kesusilaan dan Masalah Prevensinya, Sinar Grafika, Jakarta, 2002

Moelyatno., Asas-Asas Hukum Pidana, Rineka Cipta, Jakarta, 1998 
Maulana Hassan Madong., Pengantar Advokasi dan Hukum Perlindungan anak, Gramedia Widiasarana Indonesia, Jakarta, 2000.

M. Hamdan, Politik Hukum Pidana, PT. Raja Grafindo Persada, Jakarta, 1997

Paulus Hadisuprapto, Peradilan Restoratif : Model Peradilan Anak Indonesia Masa Datang. Penerbit Universitas Diponegoro, Semarang, 2006

P.A.F. Lamintang, Dasar-Dasar Hukum Pidana Indonesia, Citra Aditya Bakti, 1997

R.Wirdjono Prodjodikoro, Tindak-tindak Pidana Tertentu di Indonesia. Bandung: Eresco, Bandung, 1986,

Topo Santoso dan Eva Achjani Zulfa. Kriminologi. PT. Grafindo Persada, Jakarta, 2001

W. Friedmann., Teori dan Filsafat Hukum, Idealisme Filosofis, dan Problema Keadilan, PT. Rajalawali Pers, Jakarta, 1990

\section{B. Undang-Undang}

R. Soesilo, Kitab Undang-Undang Hukum Pidana dengan Penjelasannya Pasal Demi Pasal, Politea, Bogor, 2002.

Undang-Undang No 23 Tahun 2002 Tentang Perlindungan Anak 